\title{
Aydın Ili Turunçgil Fidanlıklarındaki ve Yeni Kurulmuş Turunçgil Bahçelerindeki Zararlılar ve Önemlilerinin Bulașıklık Oranının Saptanması
}

\section{Sezer YÜCEL'(i), Hüseyin BAȘPINAR ${ }^{* 2}$ (D)}

\author{
' Kayhan Fidancılık, Sazlı, Söke, Aydın. \\ ${ }^{2}$ Adnan Menderes Üniversitesi, Ziraat Fakültesi, Bitki Koruma Bölümü, Aydın.
}

Öz: Bu çalıșmada Aydın ilinde turunçgil fidanlıklarında ve yeni kurulmuș turunçgil bahçelerindeki zararlıların saptanması ve bunlardan önemlilerinin bulașıkık oranının belirlenmesi amaçlanmıștır. Çalıșmalar 2014 ve 2015 yıllarında, Aydın ilinde mevcut üç fidanlıkta ve her biri en az 500 adet Satsuma mandarin fidanı içeren beș yeni kurulmuș Satsuma mandarin bahçelerinde gerçekleștirilmiștir. Gerek zararılıarın saptanması ve gerekse bulașıklık oranlarının belirlenmesi için her bir çalıșma alanından periyodik olarak iki haftada bir gözle kontrol yöntemiyle belirli sayıda fidan incelenmiș ve zararlıların bulașıklık oranları hesaplanmıștır. Ayrıca türü bilinmeyen zararlıların teșhisi için örnek alınmıștır.

Sonuç olarak gerek fidanlıklarda ve gerekse yeni kurulmuş bahçelerde Helix aspersa (Gastropoda: Helicidae), Tetranychus urticae (Acarina: Tetranychidae), Aphis gossypii (Hemiptera: Aphididae), Dialeurodes citri (Hemiptera: Aleyrodidae), Aonidiella aurantii (Hemiptera: Diaspididae), Planococcus citri (Hemiptera: PseudoCoccidaee), Asymmetrasca decedens (Hemiptera: Cicadellidae) ve Phyllocnistis citrella (Lepidoptera: Gracillaridae) türleri saptanmıștır. Bu zararlıların bulașıklık oranları sezon boyunca izlenmiș ve çalıșmanın yürütüldüğü fidanlık ve yeni kurulan bahçelerde bulașıklık oranlarında dikkat çekici farklılıklar görülmüștür. Bu durumun bahçelerin bulunduğu yerdeki iklim koșulları ve her bir bahçede yapılan uygulamalardaki farklılıklardan kaynaklanabileceği düșünülmektedir.

Anahtar Kelimeler: fidanlık, Tetranychus, Dialeurodes, Helix, Aphis.

Determination of Citrus Pests and Infestation Rate of The Important Ones in Citrus Nurseries and Newly Established Citrus Orchards in Aydın Province

\begin{abstract}
It was aimed to determine pests and their infestation rates in citrus nurseries and citrus groves newly established in this study. Studies were conducted in three nurseries and in five newly established Satsuma mandarin groves having at least 500 seedling in each in the years of 2014-2015. Observations were made on the seedlings in an adequate numbers every two weeks both in the nurseries and groves. Pests were sampled for their identifications.

As a result, Helix aspersa (Gastropoda: Helicidae), Tetranychus urticae (Acarina: Tetranychidae), Aphis gossypii (Hemiptera: Aphididae), Dialeurodes citri (Hemiptera: Aleyrodidae), Aonidiella aurantii (Hemiptera: Diaspididae), Planococcus citri (Hemiptera: PseudoCoccidaee), Asymmetrasca decedens (Hemiptera: Cicadellidae), and Phyllocnistis citrella (Lepidoptera: Gracillaridae) were determined on the seedlings in nurseries and groves. Infestation rates of the pests were observed during the vegetation, and it was found significantly different both in nurseries and groves. It can be concluded that the differences could be appeard as a result of the climatic factors and different cultural practices in nurseries and groves.
\end{abstract}

Keywords: nursery, Tetranychus, Dialeurodes, Helix, Aphis.

\section{GIRIȘ}

Turunçgiller, ülkemizde gerek beslenme açısından ve gerekse ihracat getirisi bakımından çok önemli bir meyve grubudur. Yaș meyve-sebze ihracatımızın 2015 yılı itibarıyla \%40' ını karșılamaktadır (Anonim, 2016). Turunçgiller aynı zamanda tüm dünyada da en fazla yetiștirilen ve tüketilen meyve grubudur (Anonim, 2012). Dünya üzerinde yaklașık 9.7 milyon hektar alanda 135,8 milyon ton turunçgil üretimi gerçekleștirilmekte ve Türkiye 7. sırada yer almaktadır (FAO, 20I0). Türkiye'de I32 bin 74I hektar alanda, 32 bin çiftçi tarafından turunçgil üretimi yapılmaktadır (Anonim, 2016).

Gerek ülkemiz ve gerekse dünya nüfusunun her yıl artmasıyla birlikte beslenme ihtiyacına bağlı olarak diğer tarımsal ürünlerde olduğu gibi turunçgil üretiminde de artıșlar olmaktadır. Nitekim ülkemizde 2013 yılında yaklașık 3.7 milyon ton olan turunçgil üretimi 2014 yılında yaklașık 3.8 milyon tona yükselmiștir (Anonim, 2016).

Turunçgil üretimi yapılan yerlerdeki fidan gereksinimini karșılamak için her yıl çok sayıda turunçgil fidanı üretilmektedir. Kalite ve yüksek verim, ancak sağlıklı ve ismine doğru üretilen fidanlarla mümkündür. Sağlıklı turunçgil fidan üretimi, fidanlarda söz konusu olan zararlılarla uygun mücadele yöntemleri uygulanarak sağlanabilir. Bunun için ilk önce zararlı türlerin ve bulașıklık durumlarının belirlenmesi önem tașımaktadır.

Türkiye turunçgil bahçelerinde yapılan çalıșmalar sonucu; 34 hastalık etmeni, 89 zararlı, 16 nematot, 155 yabancı ot türü saptanmıștır (Uygun, 2002).

Saptanan bu zararlılar arasında Aphididae, Aleyrodidae, Coccidae, Diaspididae (Hemiptera), Tetranychidae (Acarina), Gracillaridae (Lepidoptera) gibi familyalara bağlı zararlılar bulunmaktadır. Bu zararlılar fidanlıklarda ve yeni kurulan turunçgil bahçelerinde sorun olan zararlılar olarak bildirilmiștir (Uygun ve ark., 2000). Söz konusu bu

Sorumlu Yazar: hbaspinar@adu.edu.tr Bu çalıșma yüksek lisans tezi ürünüdür.

Geliș Tarihi: 3 Ağustos 2017

Kabul Tarihi: I I Mayıs 2018 
zararlıların beslenme davranıșları gereği daha çok bitkilerin taze sürgün ve yapraklarında beslendikleri bilinmektedir. Bu zararlıların taze sürgün ve yapraklarda beslenmeyi tercih etmeleri fidan ve genç ağaçlar için önemli bir sorun olușturmaktadır. Çünkü bir an önce bitkinin meyveye yatması için fidan döneminde taze sürgün ve yaprak olușumunun teșvik edilmesi gerekmektedir. Bu durum, söz konusu bu zararlıların fidan ve genç bitkilerde hızla yüksek popülasyonlar olușturmalarına neden olmaktadır. Bahçe tesisinde zararlılardan ari fidan kullanımı çok önemlidir ve bu nedenle fidan döneminde zararlılarla etkili bir mücadele yapılması gerekmektedir. Bir çok zararlının fidanlarla yeni kurulan bahçelere bulașması ancak etkili bir mücadele sonucunda engellenir. Nitekim, Uygun ve ark. (2000), yeni kurulan turunçgil bahçelerinde Aonidiella aurantii' nin ana zararlı durumunda olduğunu ve bu zararlının yeni kurulan turunçgil bahçelerine fidanlarla bulaștığını bildirmiștir.

Doğu Akdeniz Bölgesi'nde yeni kurulmuș turunçgil bahçelerinde zararlıların entegre mücadelesi üzerinde bir Çizelge I. Fidanlıkların ve yeni kurulmuș bahçelerin koordinatları çok çalıșmalar yapılmıștır (Uygun ve Șekeroğlu, 1981, Uygun ve ark., 2000). Ancak, bu çalıșmaların dıșında ülkemizde genç turunçgil bahçeleri ve turunçgil fidan zararlılarına ilișkin herhangi bir çalıșma bulunmamaktadır. Bu çalıșmada Aydın ilinde turunçgil fidan üretimi yapılan fidanlıklarda ve yeni kurulmuș turunçgil bahçelerinde zararlıların belirlenmesi ve bulașıklık oranlarının ortaya konulması amaçlanmıștır.

\section{MATERYAL ve YÖNTEM}

Turunçgil fidanlıklarında ve yeni kurulmuş turunçgil bahçelerindeki zararlıların saptanması amacıyla 2014 ve 2015 yıllarında çalıșmalar yapılmıștır.

Turunçgil fidanlıklarındaki çalıșmalar Söke, Kuyucak ve Davutlar (Kușadası)' da toplam üç fidanlıkta yürütülmüștür. Yeni kurulmuş turunçgil bahçelerindeki zararlıların saptanması ve bulașıklık oranlarının belirlenmesi çalıșmaları, Söke' de 2, Davutlar' da 2 ve Kuyucak' da I olmak üzere toplam 5 bahçede yürütülmüștür (Çizelge I). Bahçelerin Aydın' da en yaygın üretim șekli olan troyer anaç üzerine așılanmıș satsuma mandarin çeșidinden kurulu olmasına dikkat edilmiștir.

\begin{tabular}{|c|c|}
\hline Yer & Koordinatlar \\
\hline Söke (fidanlık) & $37^{\circ} 466^{\prime} 58.8^{\prime \prime} \mathrm{N} 27^{\circ} 28^{\prime} 08.7^{\prime \prime E}$ \\
\hline Davutlar (fidanlık) & $37^{\circ} 44^{\prime} 30.2^{\prime \prime} \mathrm{N} 27^{\circ}$ I $7^{\prime} \mid 9$. I "E $^{\prime}$ \\
\hline Kuyucak (fidanlık) & $37^{\circ} 54^{\prime} 20.6^{\prime \prime} \mathrm{N} 28^{\circ} 27^{\prime} 29.4^{\prime \prime E}$ \\
\hline Söke (I. Bahçe) & $37^{\circ} 46^{\prime} 33.7^{\prime \prime} \mathrm{N} 27^{\circ} 28^{\prime} 46.2^{\prime \prime E}$ \\
\hline Söke (2. Bahçe) & $37^{\circ} 44^{\prime} 21.8^{\prime \prime} \mathrm{N} 27^{\circ} 25^{\prime} 52.6^{\prime \prime} \mathrm{E}$ \\
\hline Davutlar (3. Bahçe) & $37^{\circ} 44^{\prime} 29.8^{\prime \prime} \mathrm{N} 27^{\circ} 16^{\prime} 49.7^{\prime \prime E}$ \\
\hline Davutlar (4. Bahçe) & $37^{\circ} 45^{\prime} 02.0^{\prime \prime} \mathrm{N} 27^{\circ} \mathrm{I} 5^{\prime} 52.8^{\prime \prime} \mathrm{E}$ \\
\hline Kuyucak (5. Bahçe) & $37^{\circ} 54^{\prime} \mid 3.8^{\prime \prime} \mathrm{N} 28^{\circ} 27^{\prime} 34.0^{\prime \prime} \mathrm{E}$ \\
\hline
\end{tabular}

İncelemeye alınacak ağaç sayıları Lazarov and Grigov (196I) tarafından bildirilen yönteme göre belirlenmiștir. Buna göre, fidanlıklarda fidanların \%।5' i incelenmiștir. Çalıșmanın yürütüldüğü yeni tesis bahçelerdeki ağaç sayıları I5I-500 ağaç içerdiğinden, örneklemeler her bir bahçede 45 ağaç üzerinden yapılmıștır (Çizelge 2).

Çizelge 2. Çalıșmanın yapıldığı bahçelerde örnekleme yapılan ağaç sayılarının belirlenmesi

Bahçede bulunan ağaç sayısı (Adet) Örnekleme yapılan ağaç sayısı (Adet)

\begin{tabular}{ll}
\hline 20 & Tamam \\
$2 \mid-70$ & $10-30$ \\
$7 \mid-150$ & $2 \mid-40$ \\
$|5|-500$ & $4 \mid-50$
\end{tabular}

$501-1000$

1000’ den fazla

Gerek fidanlıklar ve gerekse yeni tesis edilmiș genç turunçgil bahçelerinde yapılan örneklemeler I5'er gün arayla gözle kontrol șeklinde periyodik olarak gerçekleștirilmiștir.

Örneklemelerde incelenen fidan ve genç ağaçların yaprak, sürgün ve gövdeleri göz ile kontrol edilmiș ve bulunan zararlılar tüm örnekleme döneminde var-yok șeklinde

\section{Ağaçların \%।5'i}

En az I 50 ağaç

kaydedilmiștir. Bulașıklık oranları her bir sayımda hesaplanmıș, yıl sonunda tüm oranların ortalamaları verilmiștir. Ayrıca, her bir sayımdaki değerlerden yıl içerisindeki minimum ve maksimum değerler de çizelgelerde ortalama olarak hesaplanan değerin altında parantez içerisinde gösterilmiștir. Çalıșmanın yapıldığı tüm fidanlıklar 
ve bahçelerde, doğrudan gözle yapılan incelemeler sırasında o anda tarafımızca tanısı yapılamayan örnekler ve ayrıca doğrudan gözle tanılanamayacak kadar küçük, örneğin Tetranychus urticae ve Dialeurodes citri gibi örnekler bulașık oldukları bitki kısımlarıyla birlikte laboratuvara getirilerek stereo mikroskop altında incelenerek doğrulukları teyid edilmiștir. Çalıșmada toplanan ve teșhisleri tarafımızca yapılamayan örnekler, gazete kağıdına sarılarak naylon poșetler içerisinde buz kutusuna alınmıș ve laboratuvara getirilmiștir. $\mathrm{Bu}$ örnekler, laboratuvarda teșhis için hazırlanarak ilgili uzmanlara gönderilmiștir.

\section{BULGULAR ve TARTIȘMA}

\section{Fidanlıklarda Saptanan Zararlılar ve Bulașıklık Durumları}

Bunun için Aydın ilinde halen fidan üretimi yapılan üç fidan ișletmesinde 2014 ve 2015 yıllarında çalıșmalar yürütülmüștür. Yapılan gözlemlerde zararlılarla bulașıklık açısından fidanlıklardaki bulașıklık oranları așağıda Çizelge 3' de gösterilmiștir.

Aydın ili' nde Helix aspersa Müler (Pulmonata: Helicidae), Tetranychus urticae Koch (Acari: Tetranychidae), Aphis gossypii Glover (Hemiptera: Aphididae) ve Phyllocnistis citrella Stainton (Lepidoptera: Gracillaridae) gözlem yapılan tüm fidanlıklarda oldukça yaygın olarak saptanmıștır. Buna karșın, Dialeurodes citri (Ashmead) (Hemiptera: Aleyrodidae) ise sadece 2015 yılında ve Söke' de saptanmıștır (Çizelge 3).

Çalıșma sırasında saptanan zararlıların ortalama bulașma oranları, minimum ve maksimum bulașıklık değerleri her bir fidanlık için ayrı ayrı verilmiștir (Çizelge 3). H. aspersa ile bulașıklık oranları incelendiğinde, çalıșmaların yürütüldüğü fidanlıklarda bulașmaların 2014 yılında ortalama \%7.9-18.3, 2015 yılında ise ortalama \%5.I-23.8 arasında gerçekleștiği

Çizelge 3. Aydın ilinde 2014 ve 2015 yıllarında fidanlıklarda saptanan zararlılar ve fidanlıkların bulașıklık oranları (\%)*

\begin{tabular}{lllllll}
\hline Zararlılar & Söke & & \multicolumn{5}{c}{ Davutlar } \\
& 2014 & 2015 & 2014 & 2015 & 2014 & 2015 \\
\hline Helix aspersa & 18.3 & 23.8 & 15.1 & 11.8 & 7.9 & 5.1 \\
& $(2.1-53.9)$ & $(1.8-80.0)$ & $(2.2-48.4)$ & $(1.6-60.1)$ & $(2.2-19.9)$ & $(1.9-34.6)$ \\
Tetranychus & 25.4 & 28.8 & 5.4 & 2.9 & 3.8 & --- \\
urticae & $(2.3-54.4)$ & $(2.1-55.2)$ & $(2.4 .-33.8)$ & $(2.2-20.0)$ & $(2.4-7.3)$ & \\
Aphis gossypii & 37.9 & 25.2 & 10.1 & 12.1 & 8.8 & 9.1 \\
& $(1.3-80.0)$ & $(2.2-68.1)$ & $(1.2-53.8)$ & $(2.6-54.3)$ & $(1.2-39.9)$ & $(2.4-40.0)$ \\
Dialeurodes citri & ---- & 7.8 & --- & --- & -- & - \\
& & $1.9-39.9)$ & & & & \\
Phyllocnistis & 25.9 & 28.7 & 12.1 & 18.2 & 8.9 & 10.1 \\
citrella & $(1.9-94.6)$ & $(1.8-94.5)$ & $(1.7-68.1)$ & $(1.8-60.0)$ & $(1.8-54.4)$ & $(1.7-68.1)$ \\
\hline
\end{tabular}

*Her bir satırda üstteki değerler ortalamayı, alttaki değerler minimum-maksimum değerleri gösterir; (----): zararlı yok. görülmüștür. En yüksek bulașıklık oranı 2014 yılında Söke' deki fidanlıkta \%53.9, Kuyucak' da \%48.4 ve Davutlar' da \%19.9 olarak saptanmıștır. 2015 yılındaki en yüksek bulașıklık oranları Söke' deki fidanlıkta \%80.0, Kuyucak' da \%60.I ve Davutlar' da \%34.6 olarak ortaya çıkmıștır. Yapılan gözlemlerde bulașmaların serin ve nemli ilkbahar ve sonbahar aylarında ortaya çıktığı ve yaygınlaștığı belirlenmiștir. Kıș ve yaz aylarında fidanların üzerinde herhangi bir H. aspersa bulașıklığı görülmemiștir. Gerek aynı fidanlık içerisinde ve gerekse farklı fidanlıklarda bulașıklık yüzdeleri arasında çok büyük varyasyonlar görülmektedir. Bu çalıșmanın yürütüldüğü fidanlık ve bahçelerde $H$. aspersa' ya karșı herhangi bir pestisit uygulaması yapılmamıștır. Gerek yıl içerisindeki mevsimsel değișimlerin ve gerekse bahçelerdeki farklı yabancı otlanma düzeylerinin $H$. aspersa bulașıklık oranlarını etkilediği ve farkların bundan dolayı ortaya çıkmıș olabileceği düșünülmektedir.

T. urticae ile bulașıklık oranları incelendiğinde, bulașmaların 2014 yılında bahçelere göre ortalama \%3.8-25.4 oranında, 2015 yılında ise ortalama \%0.0-28.8 arasında gerçekleștiği görülmektedir. En yüksek bulașıklık oranı 2014 Söke' de \%54.4, Kuyucak' da \%33.8 olmuș, Davutlarda ise \%7.3’ lük bir bulașıkıı görülmüștür. 2015 yılında ise en yüksek bulașıklıklar Söke' de \%55.2, Kuyucak' da \%20.0 olarak saptanmıș, Davutlar' da ise herhangi bir bulașma görülmemiștir. Yapılan gözlemlerde, Söke' deki fidanlıkta $T$. urticae ile bulașıklıklar mart-nisan aylarında bașlamakta ve mevsim süresince devam etmektedir. Buna karșın, Davutlar ve Kuyucak' daki fidanlıklarda yine ilkbahar aylarında bulașmalar bașlamıș, ancak yaz aylarından itibaren bulașmalar azalmıș ve sonuçta mevsim sonuna doğru herhangi bir bulașık fidan görülmemiștir.

A.gossypii ile bulașıklık oranları incelendiğinde, 2014 yılında bulașmaların ortalama olarak \%8.8-37.9 arasında, 2015 yılında ise \%9.I-25.2 arasında ortaya çıktığı saptanmıștır. En yüksek bulașıkık 2014 yılında \%80.0 ile Söke' de ortaya çıkmıș, bunu \%53.8 ile Kuyucak ve \%39.9 ile Davutlar' daki fidanlıklar izlemiștir. 2015 yılında ise en yüksek bulașıklık \%68.I ile Söke' de görülmüș, Kuyucak' da \%54.3 ve Davutlar' da \%40.0 olarak ortaya çıkmıștır. Yapılan gözlemlerde, bulașmaların mart-nisan aylarında bașladığı, yaz aylarında ortadan kalktığı ve eylül-ekim aylarında tekrar ortaya çıktığı ve ilkbahar aylarına göre daha yüksek bulașıklık oranlarına yükseldiği saptanmıștır.

D. citri ile bulașıklık oranları incelendiğinde, 20/4 yılında çalıșmanın yürütüldüğü tüm fidanlıklar zararlıdan ari 
bulunmuștur. Ancak, 2015 yilında da Davutlar ve Kuyucak' daki fidanlıklarda bulașma saptanmamıș, sadece Söke' deki fidanlıkta ortalama \%7.8 oranında bir bulașma saptanmıștır. Bulașmalar ağustos ayından bașlamak üzere gözlemlenmiș ve ekim ayına kadar bulașıklık saptanmıștır. Bulașmalar ekim ayında maksimum düzeye yükselmiștir.

P. citrella ile bulașıklıklar incelendiğinde, 2014 yılında fidanlıklara göre ortalama \%8.9-25.9 oranında, 2015 yılında ise \%।0.I-28.7 oranında saptanmıștır. En yüksek bulașıklık oranı 2014 Söke' de \%94.6, Kuyucak' da \%68.I ve Davutlar' da \%54.4 oranında belirlenmiștir. 2015 yılında ise en yüksek bulașıklıklar Söke' de \%94.5, Kuyucak' da \%60.0 ve Davutlar' da \%68.I olarak saptanmıștır. P. citrella ile bulașmaların haziran ayından itibaren görülmeye bașlandığı belirlenmiștir. Bulașmalar mevsim ilerledikçe artmakta sonbahar sürgünleriyle birlikte en yüksek düzeye ulașmaktadır.

Ayrıca, çalıșmanın yürütüldüğü bu fidanlıkların dıșında, Adana, Hatay ve Mersin' den de fidan getirtilerek Aydın ili tarım alanlarında bahçe tesis edildiği gözlenmiștir. Bu çalıșmanın yürütülmesi sırasında, bazı üreticilerin kișisel iletișimleri ile tarafımıza bașvuruları sonucunda, tarafımızca yapilan incelemelerde Aonidiella aurantii, Planococcus citri, Coccus hesperidum ve Iceya purchasi gibi zararlılar gözlemlenmiștir.

\section{Yeni Kurulan Bahçelerde Saptanan Zararlılar ve Bulașıklık Durumları}

Aydın ili' nde gözlem yapılan yeni kurulmuș turunçgil bahçelerinde 2014 ve 2015 yıllarında Helix aspersa Müler (Pulmonata: Helicidae), Aphis gossypii Glover (Hemiptera: Aphididae), Asymmetrasca decedens (Paoli) (Hemiptera: Cicadellidae), Phyllocnistis citrella Stainton (Lepidoptera: Gracillaridae) oldukça yaygın olarak saptanmıștır. Buna karșın, Tetranychus urticae Koch (Acari: Tetranychidae), Aonidiella aurantii Maskell (Hemiptera: Diaspididae), Dialeurodes citri (Ashmead) (Hemiptera: Aleyrodidae), ve Planococcus citri Risso (Hemiptera: Pseudo Coccidae) bazı bahçelerde saptanmıș, bazı bahçelerde ise saptanamamıștır. Ceroplastes cinensis Del Gercio (Hemiptera: Coccidae) ise sadece 2015 yılında ve bir bahçede saptanmıștır (Çizelge 4). Saptanan zararlıların bulașıklık durumları ve yayılıșları değerlendirilecek olursa, yeni kurulan bahçelerin hepsinde A. decedens saptanmıștır. Ancak, ağaçların yapraklarında ve yeșil aksamında bu zararlıya ait nimf görülmemiștir. Bu zararının hareketli olması bulașma oranı açısından sağııkı bir değerlendirme yapmamızı engellemiștir. Ancak, söz konusu bu zararlının gözle yaptığımız incelemeler sonucunda, yeni kurulmuș turunçgil bahçelerinde çok yaygın olduğu, ancak yüksek popülasyonlara ulașamadığı gözlemlenmiștir.

Yeni kurulan turunçgil bahçelerinde saptanan bir diğer zararlı C. sinensis olmuștur. Bu zararlı sadece Söke' deki bir bahçede ve çalıșmanın ikinci yılında I (bir) birey olarak bir sürgünde görülmüștür. Bulașık fidanla veya dıșarıdan getirilen bulașı bitki materyalleri ile bahçeye taşındığı düșünülmektedir.

Yukarıda belirtilen bu iki zararlıdan A. decedens' in hareketli ve uçucu olması ve tüm bahçelerde çok yaygın olarak saptanması nedeniyle bu zararlıya ilișkin sağlıklı bir bulașıklık oranı ortaya konulamamıștır. Bunun yanı sıra diğer bir zararlı $C$. sinensis ise tüm çalıșma süresince sadece I birey olarak saptandığından bulașıklık oranları Çizelge 4' de verilmemiștir. Bunun yerine bu iki zararlı ile ilgili olarak çizelge'de açıklayıcı kısa bilgiler verilmiștir.

Yeni kurulan turunçgil bahçelerinde saptanan diğer bir zararlı, H. aspersa' dır. Bu zararlının bulașıklık oranları Çizelge 4' de gösterilmiștir. Buna göre, çalıșmanın yapıldığı beș bahçenin de $H$. aspersa ile bulașık olduğu görülmektedir. Ortalama bulașıklık oranları bahçelere göre 2014 yılında \%9.0-23.9 arasında, 2015 yilında ise \%II.I-25.2 arasında değișmiștir. $H$. aspersa' nın hemen hemen tüm yıl boyunca yeni kurulmuş turunçgil bahçelerinde bulunduğu saptanmıștır. Bulașıklık oranları havanın nemli olduğu ilkbahar ve sonbahar aylarında artmıștır. Bulașmaların martnisan aylarında bașladığı ve mevsim süresince devam ettiği belirlenmiștir.

T. urticae' nin bahçelere göre bulașiklık oranları incelendiğinde, beș bahçeden 2014 yilında sadece Söke' deki 2. bahçenin $T$. urticae ile bulașık olduğu ve bulașma oranının ortalama \%5,2 olduğu, en yüksek bulașıklığın bu bahçede \%15.I olarak gerçekleștiği görülmektedir. Denemenin ikinci yilı olan 2015 yilında ise Söke' deki I. ve 2. bahçeler bulașık olarak saptanmıștır. Bulașma oranları bahçelere göre ortalama değer olarak \%2.9-7.9 arasında gerçekleșmiștir. Gerek Davutlar' daki 3. ve 4. bahçeler ile Kuyucak' daki 5. bahçede herhangi bir bulașma görülmemiștir. Bulașmaların șubat-mart aylarından itibaren bașladığı ve ekim-kasım aylarına kadar sürdüğü belirlenmiștir.

Yeni kurulan bahçelerde 2014 yılında Aonidiella aurantii ile herhangi bir bulașıklık gözlenmemiș, 2015 yılında ise Söke'deki 2. bahçede ve Davutlar' daki 3. ve 4. bahçelerde \%6.8' e kadar ulașan bulașıklık gözlenmiștir.

A. gossypii bulașıklık oranlarına bakıldığında 2014 yııında bulașıklıkların bahçelere göre ortalama \%5.8-10.0 arasında gerçekleștiği görülmektedir (Çizelge 4). 2015 yilında ise bu ortalama oranlar \%6.9-11.9 arasında saptanmıștır. En yüksek bulașma oranları hem 2014 hem de 2015 yıllarında \%42.5' luk bulașma ile Davutlar' daki 3. ve 4. Bahçelerde gerçekleșmiștir. Çalıșma süresince, ilk bulașmaların her iki yılda da mart ayında bașladığı ve tüm vegetasyon süresince devam ettiği, bulașmaların her iki yılda da ekim sonunda sona erdiği belirlenmiștir. Bulașıklık oranlarının nisan-mayıs aylarında en yüksek düzeylere çıktığı gözlenmiștir.

D. citri ile bulașıklık sadece Davutlar' daki 3. bahçede 
Çizelge 4. Aydın ilinde 2014 ve 2015 yıllarında yeni kurulmuș bahçelerde saptanan zararlılar ve bahçelerin bulașıklık oranları (\%)*

\begin{tabular}{|c|c|c|c|c|c|c|c|c|c|c|}
\hline \multirow{2}{*}{$\begin{array}{c}\text { Bahçeler } \\
\text { Zararlılar/Yıllar }\end{array}$} & \multicolumn{2}{|c|}{ I.Bahçe } & \multicolumn{2}{|c|}{ 2.Bahçe } & \multicolumn{2}{|c|}{ 3.Bahçe } & \multicolumn{2}{|c|}{ 4.Bahçe } & \multicolumn{2}{|c|}{ 5.Bahçe } \\
\hline & 2014 & 2015 & 2014 & 2015 & 2014 & 2015 & 2014 & 2015 & 2014 & 2015 \\
\hline Helix aspersa & $\begin{array}{l}23.9 \\
(3.9- \\
40.0)\end{array}$ & $\begin{array}{l}25.2 \\
(7.1- \\
39.9)\end{array}$ & $\begin{array}{l}13.9 \\
(2.0- \\
24.8)\end{array}$ & $\begin{array}{l}16.1 \\
(4.3- \\
24.7)\end{array}$ & $\begin{array}{l}18.1 \\
(2.0- \\
40.0)\end{array}$ & $\begin{array}{l}22.6 \\
(2.4- \\
40.0)\end{array}$ & $\begin{array}{c}9.0 \\
(2.1- \\
20.0)\end{array}$ & $\begin{array}{l}I I . I \\
(2.5- \\
20.0)\end{array}$ & $\begin{array}{l}12.6 \\
(2.0- \\
24.1)\end{array}$ & $\begin{array}{l}13.9 \\
(2.4- \\
24.8)\end{array}$ \\
\hline Tetranychus urticae & ---' & $\begin{array}{c}2.9 \\
(1.3- \\
17.9)\end{array}$ & $\begin{array}{l}5.2 \\
(1.0- \\
15.1)\end{array}$ & $\begin{array}{c}7.9 \\
(1.2- \\
20.0)\end{array}$ & ---' & --- & ---' & --- & --- & --- \\
\hline Aonidiella aurantii & --- & --- & --- & $\begin{array}{c}1.5 \\
(1.0-6.8)\end{array}$ & --- & $\begin{array}{c}0.9 \\
(1.0-4.5)\end{array}$ & --- & $\begin{array}{c}1.9 \\
(1.0-6.8)\end{array}$ & --- & ---- \\
\hline Aphis gossypii & $\begin{array}{c}8.2 \\
(1.2- \\
26.8)\end{array}$ & $\begin{array}{c}9.1 \\
(1.3- \\
27.0)\end{array}$ & $\begin{array}{c}6.9 \\
(1.1- \\
24.8)\end{array}$ & $\begin{array}{c}7.2 \\
(1.3- \\
24.9)\end{array}$ & $\begin{array}{c}8.1 \\
(1.2- \\
42.5)\end{array}$ & $\begin{array}{c}9.1 \\
(1.2- \\
42.5)\end{array}$ & $\begin{array}{l}10.0 \\
(1.1- \\
42.5)\end{array}$ & $\begin{array}{l}11.9 \\
(1.3- \\
42.5)\end{array}$ & $\begin{array}{c}5.8 \\
(1.2-27)\end{array}$ & $\begin{array}{c}6.9 \\
(1.1- \\
26.9)\end{array}$ \\
\hline $\begin{array}{l}\text { A. decedens+ } \\
\text { E. decipiens }\end{array}$ & & & Tüm bahç & lerde yaygı & ve gözlem & yapılan tüm & ağaçlarda & ptanmıștır. & & \\
\hline Ceroplastes cinensis & & Sök & jeki birinci & ahçede 201 & 5 yilinda sa & ece bir ağa & ta bir ade & irey saptan & nıștır. & \\
\hline Dialeurodes citri & ---- & & ---- & & ---- & $\begin{array}{c}2.0 \\
(0.4-6.8)\end{array}$ & ---- & ---- & ---- & ---- \\
\hline Planococcus citri & $\begin{array}{c}2.5 \\
(1.0-8.9)\end{array}$ & $\begin{array}{c}2.4 \\
(1.0- \\
11.2)\end{array}$ & $\begin{array}{c}3.1 \\
(1.0-8.9)\end{array}$ & $\begin{array}{c}3.9 \\
(1.1- \\
13.2)\end{array}$ & $\begin{array}{c}1.3 \\
(1.0-6.8)\end{array}$ & $\begin{array}{c}3.7 \\
(0.9- \\
13.2)\end{array}$ & --- & ---- & --- & --- \\
\hline Phyllocnistis citrella & $\begin{array}{l}15.1 \\
(1.1- \\
51.2)\end{array}$ & $\begin{array}{l}38.1 \\
(1.0- \\
100)\end{array}$ & $\begin{array}{l}12.2 \\
(1.1- \\
49.3)\end{array}$ & $\begin{array}{l}38.2 \\
(1.0- \\
100)\end{array}$ & $\begin{array}{l}13.9) \\
(1.2- \\
51.1)\end{array}$ & $\begin{array}{c}37.9 \\
(10.9- \\
100)\end{array}$ & $\begin{array}{l}15.6 \\
(1.1- \\
51.2)\end{array}$ & $\begin{array}{l}39.1 \\
(0.9- \\
100)\end{array}$ & $\begin{array}{l}11.9 \\
(1.1- \\
49.2)\end{array}$ & $\begin{array}{l}37.5 \\
(1.0- \\
100)\end{array}$ \\
\hline
\end{tabular}

* Her bir satırda üstteki değerler ortalamayı, alttaki değerler minimum-maksimum değerleri gösterir;(----): zararlı yok.

ve 2015 yılında gözlenmiștir. Tüm yıl boyunca yapılan gözlemlerde, bulașıklık sadece nisan ve eylül aylarında olmak üzere iki ay için saptanmıștır. Ortalama olarak bulașıklık \%2.0 düzeyinde gözlenmiștir.

Planococcus citri, Söke' deki I. ve 2. bahçelerde ve Davutlar' daki 3. bahçede saptanmıștır. Bulașıklık oranları bahçelere göre her iki yıl da dikkate alınırsa, ortalama \%।.3-3.9 arasında değișmektedir. En yüksek bulașıklıklar, 2014 yılında Söke' deki I. ve 2. bahçelerde \%8.9, 2015 yilında Söke' deki 2. bahçe ile Davutlar' daki 3. bahçede \%।3.2 olarak gerçekleșmiștir. En yüksek bulașıklıkların ağustos ve eylül aylarında ortaya çıktığı görülmüștür.

Çalıșmanın yürütüldüğü yeni kurulan bahçelerde, Phyllocnistis citrella'nın bulașıklık oranlarına bakıldığında, 2014 yılında ortalama bulaşıklıkların tüm bahçelerde \% 10 ' un ve 2015 yılında ise \%35' in üzerinde olduğu belirlenmiștir. En yüksek bulașıklık oranları 2014 yılında tüm bahçelerde \%49.2-5I.2 arasında seyretmiștir. Çalıșmanın ikinci yılı 2015' de ise tüm bahçelerde bulașıklık oranları \%।00 olarak saptanmıștır. Çalıșma süresince zararlının ortaya çıkıșıla ilgili gözlemlerde, ilk bulașmaların her iki yılda da haziran ayının sonlarında bașladığı ve tüm vegetasyon süresince devam ettiği, bulașmaların her iki yılda da aralık ayında sona erdiği belirlenmiștir. Gözlem yapılan tüm bahçelerde bulaşıklıklar haziran-aralık ayı sonu arasında sürmüștür.

Tüm zararlılar genel olarak birlikte incelendiğinde zararlılara ilișkin așağıdaki değerlendirmeler yapılabilir. H. aspersa, gerek fidanlık ve gerekse yeni kurulan bahçelerde yaygın olarak görülen zararılılar arasında yer almıștır. Özellikle genç yapraklar ve yeșil aksam üzerinde beslenerek yüksek popülasyonlara ulașabildiği ve önemli zararlar olușturabildiği gözlenmiștir. Nitekim, yapılan bir çalșmada da genç fidanlarda yeșil aksamın yanı sıra fidanın gövde kabuğu ile de beslendiği ve fidanda önemli hasarlar olușturduğu bildirilmiștir (Anonim, 20I4). Yabancı otların bol bulunduğu ve ortamın nemli olduğu yerlerde tarımsal üretimde de ekonomik önemi olan bir zararlıdır. Polifag olması nedeniyle yüksek popülasyona ulaștığı tarımsal alanlarda önemli bir zararlı konumuna gelebilir. Dünyanın bir çok ülkesinde yaygın olarak bulunmaktadır (Dekle ve Fasulo, 2009). Çalıșmanın yürütüldüğü hemen tüm fidanlık ve yeni kurulan turunçgil bahçelerinde saptanmış olup, otlu ve nemli ortamlarda özellikle havaların serin olduğu ilkbahar ve sonbahar aylarında \%80' lere ulașan bulașıklık oranları saptanmıștır.

Çalıșmada saptanan bir diğer zararlı T. urticae hem fidanlık ve hem de yeni kurulan bahçelerde yaygın olarak bulunmaktadır. Otlu bahçe ve fidanlıklarda daha yüksek popülasyonlara ulașabilir. İlk bulașmaların gözden kaçması nedeniyle, üreticiler tarafından geç fark edilmekte ve bu durumda da mücadele için geç kalınmıș olabilmektedir. Dünyanın bir çok ülkesinde T. urticae polifag olarak bir çok bitkide zarar yapmaktadır. Turunçgillerde özellikle genç yaprak ve sürgünlerde önemli zararlar olușturmaktadırlar (Vacante, 20I0). T. urticae' nin İspanya'daki turunçgillerde (Martinez-Ferrer ve ark., 1998) ve Kaliforniya' daki turunçgil 
fidanlıklarında (Anonim, 20I5) en önemli zararlılardan biri olduğu ortaya konulmuștur. Gerek fidanlık ve gerekse turunçgil bahçelerinde çoğu zaman yanlış ve gereksiz olarak kullanılan insektisitler, $T$. urticae' nin doğal düșmanlarını da olumsuz etkilemekte ve bu zararlının populasyonunu baskı altında tutan en önemli faktörlerden doğal düșmanların ortamdan uzaklașmasıyla zararının popülasyonları hızla yükselebilmektedir. Bu durumda, T. urticae ile mücadelede akarisitlere daha sık bașvurulmakta ve akarisitlere dayanıklılık sorunu nedeniyle de yeterli bașarı elde edilememektedir (Vacante, 2010).

Birçok bitkide önemli zararlar olușturan $A$. gossypii, bu çalıșmada da turunçgillerde belirli dönemlerde saptanmıștır. Poifag ve kozmopolit bir zararlı olduğu bilinmektedir (Lodos, 1982). Özellikle genç yaprak ve sürgünlerde beslenmeleri sonucu önemli zararlar meydana getirmektedir. Akdeniz ülkelerindeki turunçgillerde önemli bir zararlı olarak bildirilmiștir (Uygun ve ark., 20I2). Ayrıca, bir çok virusun vektörü olarak da bilinmektedir (Lodos, 1982). Özellikle turunçgil Tristeza virüsü turunçgiller açısından çok önemlidir. Hem yetișkin turunçgillerde ve hem de turunçgil fidanlarında çok önemli bir hastalık olup, $A$. gossypii ile de tașınabildiği gösterilmiștir (Roistacher ve ark., 1984).

Yapılan gözlemlerde, söz konusu bu zararlının turunçgillerde ilkbahar ve sonbahar aylarında bulașıklık oranlarının yükseldiği belirlenmiștir. Yılın bu mevsimleri nemli ve kısmen serin olup, yaprakbitinin istediği ekolojik koșulların bulunduğu dönemdir. '̇zmir' de Satsuma mandarin bahçelerinde yapılan bir çalıșmada (Yoldaș, 20II), yaprakbitlerinin nisan-temmuz aylarında turunçgil bahçelerinde görüldüğü ve haziran ayında en yüksek popülasyon düzeylerine ulaștığı belirlenmiș ve yaprakbiti popülasyonu sadece bir tepe noktası olușturmuștur. Oysa $\mathrm{ki}$, bu tez çalıșmasında ilkbahar ve sonbahar aylarında iki yoğun bulașıklık dönemi saptanmıș olup, bu durum bize popülasyonun iki tepe noktası olduğuna ișaret eder. Burada iki tepe noktası elde edilmesinin bir nedeni olarak, çalıșmanın yürütüldüğü turunçgil ağaçlarının çok genç olușu ve yapılan gübrelemelerle sürgün olușumunun teșvik edilmesi sonucunda, hem ilkbahar ve hem de sonbaharda yoğun sürgün olușumunun ortaya çıkması gösterilebilir.

$\mathrm{Bu}$ çalıșmanın yürütüldüğü turunçgil fidanlıkları ve genç turunçgil bahçelerinde saptanan bir diğer zararlı da $D$. citri' dir ve yapılan çalışmalarda turunçgillerde önemli ve yaygın bir zararlı olarak bildirilmiștir (Lodos, 1982; Yumruktepe ve Uygun, 1994; Argov ve ark., 2012). Ancak, bu çalıșmada Söke' deki fidanlıkta ve Davutlar' daki 3. Bahçede saptanmıștır. Bulașıklık oranlarının özellikle yaz sonu ve sonbahar bașında arttığı gözlenmiștir. Bu çalıșmada, D. citri' nin çok yaygın olarak bulunmama nedeni elde edilen bulgularla açıklanabilecek bir durum değildir. Ancak, yetiștirilen tür ve çeșit özellikleri ve mevcut doğal düșman baskısı $D$. citri' nin yayılıșına etki edebilir. Bilindiği gibi, Doğu Akdeniz Bölgesi' nde bir çok turunçgil tür ve çeșiti yaygın olarak yetiștirilirken, Aydın ilinde daha çok Satsuma mandarin ve Washington Navel portakal çeșitleri hakimdir. Ayrıca, Doğu Akdeniz Bölgesi' nde daha yoğun bir pestisit kullanımı söz konusudur ve doğal düșmanların bu bölgede daha çok zarar görmüș olabileceği düșünülmelidir. Bu nedenle, zararının popülasyon düzeyleri ve yayılıșları bölgeler arasında farklılık gösterebilir.

P. citrella bu çalıșmada hem bulașıklık açısından ve hem de yayılıș itibarıyla en yaygın bulunan zararlı olmuștur. Bilindiği gibi Güneydoğu Asya kökenli olan bu zararlı, 1994 yılında ülkemizdeki Doğu Akdeniz turunçgil alanlarına bulașmıș ve çok hızlı bir șekilde tüm turunçgil alanlarına yayılmıștır (Uygun ve Karaca, 1994). Turunçgillerde genç ve taze sürgünlerdeki yapraklara bırakılan yumurtalardan çıkan larvalar yaprağın iki epidermisi arasında galeriler açarak beslenir ve yılda 13-15 döl verebilmektedir. Gerek turunçgil fidanlıklarında ve gerekse yeni kurulmuş turunçgil bahçelerindeki genç ağaçlarda hızlı sürgün olușumu nedeniyle çok önemli zararlar vermektedir. (Bașpınar, 1996; Uygun ve ark.,2010). Nitekim bu çalıșmada da hem turunçgil fidanlarında ve hem de yeni kurulmuș turunçgil bahçelerinde \% 100 ' e varan bulașıklıklar saptanmıștır. Bulașmalar daha çok yaz aylarında bașlamakta ve yıl boyu olușan tüm sürgünlere zamanla yayılarak tüm ağaçlar bulașik hale gelmektedir. Bu nedenle sürgün olușumunu erken ilkbahar aylarında teșvik ederek mevsimin ilerlediği ve zararlının daha yüksek popülasyonlara ulaștı̆ı yaz ve sonbahar aylarında pișkin sürgün olușumunun sağlanması önerilmektedir (Uygun ve ark., 2010).

Bu çalıșmada saptanan bir diğer zararlı ise, $A$. aurantii olup, çalıșmanın ikinci yılı olan 2015 yılında Davutlar' daki 3. Bahçede görülmüștür. Bulașıklık oranı \%6.5 civarında saptanmıștır. Bu zararlı sabit yașayıșlı olup, bulașık fidanlarla yeni tesis bahçelere bulaștığı ve buradan da bahçe içerisine yayıldığı bilinmektedir. Bu çalıșmada, birinci yıl yapılan gözlemlerde, muhtemelen bahçe bulașık ancak popülasyon çok düșük olduğu için tarafımızca saptanamamıș olabilir. Ya da bulașma ikinci yıl bir șekilde zararlıyla bulașık turunçgil meyveleri veya diğer bitki kısımları veya bulașık süs bitkileri gibi bitki materyallerinin bahçeye sokulmasıyla gelmiş olabilir. Bu zararlının turunçgillerin en önemli zararlılarından biri olduğu ve zararlı ile bulașık fidanlarla yayıldığı bilinmektedir (Uygun ve ark., 2010). Bu nedenle, temiz fidanlarla bahçe tesisi çok önemlidir.

Turunçgillerin çok önemli zararlılarından birisi de bilindiği üzere P. citri' dir. Bu zararlı yeni kurulmuș bahçelerden I., 2. ve 3. bahçelerde belirlenmiștir. Bu zararlı, Aydın ilinde Kuyucak gibi nemin düșük olduğu iç bölgelerde popülasyon olușturmamaktadır. Daha çok, Davutlar, Kușadası ve Bağarası gibi nemin yüksek olduğu bölgelerde zararlı konumuna geldiği bilinmektedir. Ancak, son yıllarda Aydın 
ilinin genelinde gerek yeni barajların yapılması ve sulamaların artması ve gerekse jeotermal enerji kaynaklarının elektrik üretiminde kullanılmasıyla ortama yüksek miktardaki su buharı salımı gibi nedenlerle orantılı nemin yükseldiği ve zararlının yayılış alanını genișlettiği gözlenmektedir. Hareketleri çok yavaș olduğu için yeni kurulmuş bahçelere bulașık fidanlar aracılığıyla gelebileceği düșünülmektedir. Ayrıca, zeytin, zakkum, nar, bağ vb. birçok konukçusu vardır (Lodos, 1982) ve bu konukçuların Aydın ilinde geniș bir üretim alanı mevcuttur. Bu nedenlerle, sağlıklı bahçelerin korunması ve yeni tesis bahçelere bulașmaların önlenmesi için mutlaka sanitasyon önlemlerinin tam olarak alınması gereklidir.

Çalıșmada saptanan zararlılardan $A$. decedens, daha çok pamuk ve mısır alanlarında yaygın olarak bulunan bir zararlı olup, turunçgil bahçelerine sonbahar aylarında pamuk hasatı sırasında gelmektedir (Bașpınar ve Uygun, 1992). Aslında turunçgillerde üreyerek popülasyon olușturmazlar. Daha çok yabancı ot mücadelesi yapılmayan bahçelerde yüksek popülasyon oluștururlar (Bașpınar ve Uygun, 1992). Bu zararlının popülasyonunu pamuk ve mısır alanlarında baskı altına almanın turunçgillerde zarar olușturmasını engellemek açısından önemli olduğu düșünülmektedir. Turunçgil bahçelerinde de yabancı ot mücadelesi zararlı popülasyonunu düșürecektir.

Ülkemizde bahçe tesislerinde kullanılacak fidanlar kontrolsüz bir șekilde ne yazık ki bölgeden bölgeye tașınabilmekte ve üzerinde de bir çok zararlının yeni bahçe tesis edilecek bölgeye tașınmasına yol açmaktadır. Nitekim, üreticilerin bildirimi sonucunda, çalıșmalarımızı yürüttüğümüz dönemde Doğu Akdeniz Bölgesi’ nden gelen fidanlarda birçok zararlı tür saptanmıștır. Bunlar A. aurantii, C. hesperidum, P. citri ve I. purchasi gibi türlerdir. Ancak, söz konusu bu zararlılar halen Aydın ilinde turunçgil bahçelerinde mevcuttur. Burada vurgulanmak istenen asıl konu, diğer bölgelerden zararlıların fidanlarla yeni bölgelere bu șekilde tașınma olasılığının yüksek olușudur.

\section{SONUC}

Sonuç olarak, turunçgil üretiminde özlenen verimin alınması diğer bakım ișlemlerinin yanı sıra bitki koruma uygulamalarının da ekolojik ve ekonomik esaslar içerisinde yürütülmesine bağlıdır. Burada daha ișin bașında, yani bahçe tesisinden itibaren bitki koruma prensiplerine uyulması gerekmektedir. Bunların da en önemlisi temiz üretim materyalinin kullanılmasıdır. Yeni tesis edilmiș bahçelerde sürekli gözlemlerle zararlıların izlenmesi, ileriki dönemde yerleșik yüksek popülasyonların olușumunu engellemek üzere gerekli önlemlerin zamanında alınmasına yardımcı olacaktır.

\section{KAYNAKLAR}

Anonim (20/2) 14. Uluslararası Turunçgil Kongresine Görkemli Lansman. Akdeniz Ihracatçı Birlikleri Genel Sekreterliği, Erișim:

http://www.akib.org.tr/tr/content.asp? PID $=\{$ C76B3F722978-47BA-B408-9854394D2BE6 (Erișim Tarihi: 03/0I/2016).
Anonim (2014) UC IPM Online, Statewide Integrated Pest Management Program,University of California, Agricultural and Natural Resources, Erișim: http://www.ipm.ucdavis.edu (Erișim Tarihi: 03/0I/2016).

Anonim (20I5) UC IPM Online, Statewide Integrated Pest Management Program, University of California, Agricultural and Natural Resources, Erișim: http://www.ipm.ucdavis.edu (Erișim Tarihi: 03/0I/2016).

Anonim (2016) Yaș Meyve Sebze İhracatçıları Birliği Değerlendirme Raporu, 2014-20150cakAralık. Erișim: http://www.akib.org.tr/files/downloads/arastirmaraporla ri/ ysm/yms-degerlendirme-raporu-ocak-aralik-20I5.pdf. (Erișim Tarihi: 03/0I/2016).

Argov Y, Uygun N, Porcelli F, Bașpınar H (2012) Aleyrodidae. In: Integrated Control of Citrus Pest in the Mediterranean Region (Vacante, V. And Gerson, U., Eds.) Bentham e Books, UAE.

Bașpınar H, Öncüer C, Aldemir O, Çakmak i (1996) Aydın ili Turunçgil Bahçelerinde Turunçgil Yaprak Galerigüvesi, Phyllocnistis citrella Stainton (Lepidoptera: Gracillaridae)' nın Genel Durumu, Zararı ve Doğal Düșmanları Üzerinde Çalıșmalar. Türkiye III. Entomoloji Kongresi Bildirileri, 24-28 Eylül 1996, A. Ü. Ziraat Fakültesi, Bitki Koruma Bölümü, Ankara, 9-।3.

Bașpınar H, Uygun N (1992) Adana illi Turunçgil Bahçelerinde Asymmetrasca decedens (Paoli) ve Empoasca decipiens Paoli (Homoptera: Cicadellidae)' in Populasyon Dalgalanmaları ve Zararı Üzerinde Çalıșmalar. Türkiye II. Entomoloji Kongresi Bildirileri, 28-3I Ocak 1992, Adana, 533-540.

Dekle G W, Fasulo T R (2009) Brown Garden Snail, Helix aspersa Müller (Gastropoda: Pulmonata: Helicidae). Erișim http://edis.ifas.ufl.edu/document_in396 (Erișim Tarihi: 03/01/2016).

FAO (2010) Statistical Yearbook of the Food And Agricultural Organization for the United Nations. Erișim: http://www.fao.org/docrep/018/i3 107e/i3 107e03.pdf (Erișim Tarihi: 03/0I/2016).

Lazarov A, Grigov P (196I) Karantina Rastenijata Zemizdat, Sofia.

Lodos N (1982) Türkiye Entomolojisi II: Genel, Uygulamalı ve Faunistik. E.Ü. Ziraat Fakültesi Yayınları, Ege Üniversitesi Matbaası, Bornova-İzmir.

Martinez-Ferrer M T, Jacas-Miret J A, Ripolles-Mores J L Aucejo-Romero S (1998) Sampling Plans for Tetranychus urticae (Acari: Tetranychidae) for IPM Decisions on Clementines in Spain. IOBC/WPRS Bulletin, 29 (3): 303.

Roistacher C N, Bar-Joseph M, Gumpf D J (1984) Transmission of Tristeza and Seedling Yellows Tristeza Virus by Small Populations of Aphis gossypii. Journal of Plant Disease, 68: 494-496.

Uygun N (2002) Meyve ve Bağ Zararlıları. Çukurova Üniversitesi Ziraat Fakültesi Yayınları, No: 252, Adana. 
Uygun N, Hermoso de Mendoza A, Bașpinar H (2012) Aphididae. In: Integrated Control of Citrus Pest in the Mediterranean Region (Vacante, V. And Gerson, U., Eds.) Bentham e Books, UAE.

Uygun N, Karaca I (1994) Turunçgil Yaprak Galeri Güvesi (Phyllocnistis citrella Stainton) (Citrus Leafminer). Turunçgil Bülteni, Ç. Ü. Subtropik Meyveler Araștırma ve Uygulama Merkezi, I3, I-2.

Uygun N, Karaca I, Șenal D (2000) Çukurova' da Yeni Kurulan Bir Turunçgil Bahçesinde Zararlılara Karșı Integre Savaș Çalıșmaları. Türkiye IV. Entomoloji Kongresi Bildirileri, I2-15 Eylül 2000, Aydın, 157-166.

Uygun N, Șekeroğlu E (198I) Yeni Kurulan Turunçgil Bahçelerinde Tüm Savaș Çalıșmaları. Ç.Ü. Ziraat Fakültesi Yayınları, No: 150. Bilimsel Araștırma ve Incelemeler, No: 41 , $13 \mathrm{~s}$
Uygun N, Ulusoy M R, Karaca I, Satar S (2010) Meyve ve Bağ Zararlıları. ISBN: 978-605-397-067-5. Özyurt Matbaacilık, Adana.

Vacante $V(2010)$ Citrus Mites. Identification, Bionomy and Control. CABI International, ISBN-I3: 978 I 84593498 9, MPG Book Group, London.

Yoldaș Z, Güncan A, Koçlu T (20II) Seasonal Occurrence of Aphids and Their Natural Enemies in Satsuma Mandarin Orchards in Izmir, Turkey. Türk Entomoloji Dergisi, 20II, 35 (I): 59-74.

Yumruktepe R, Uygun N (1994) Doğu Akdeniz Bölgesi Turunçgil Bahçelerinde Saptanan Yaprakbiti (Homoptera: Aphididae) Türleri ve Doğal Düșmanları. Türkiye III.Biyolojik Mücadele Kongresi Bildirileri, 25-28 Ocak 1994, İzmir, I-I2. 